\title{
Mental Health How (re)Constitutive Tool in Ways of Living of Visually Impaired Persons

\section{Érico Gurgel Amorim ${ }^{1}$, Jacileide Guimarães ${ }^{2}$,} Olivia Morais de Medeiros Neta ${ }^{3}$ Ingrid Gurgel Amorim4, Rafael Otávio Bezerra de Morais ${ }^{5}$

\section{Abstract}

Objective: to analyze mental health in the face of visual impairment, identifying the stages of psychological distress in the encounter with the not seeing.

Method: This is an exploratory study with a qualitative approach. Fifteen adults with visual impairment attended at a specialized ophthalmology ambulatory in a university hospital in the city of Natal, Rio Grande do Norte, Brazil were studied, from June to August 2015, through a semistructured interview. The speeches were analyzed based on the theory of mourning.

Results: the results showed that the mental health of the visually impaired person is structured through a normative apparatus constituted of individual and social attributes dynamically constructed. These attributes are related to the constitution of stages of mourning, characterized by shock, denial, bargaining, depression, and acceptance. The mental health of the visually impaired person contemplates the phases of normal mourning, established before the condition of visual loss, as structuring mode in a process of personal reconstruction, reflected in the ways of walking the life, proper from each one.

Conclusion: With this study, it was possible to understand the ways of constitution and reconstitution of people in dealing with a new condition, the one of visual impairment, providing caregivers, family, and society with an ethical spirit and solidarity, more compliant and humane in the to deal with people with disabilities.
1 Federal University of Rio Grande do Nort,UFRN. Medical School. Natal, Brazil.

2 Federal University of Rio Grande do Norte,UFRN. Health School. Natal, Brazil.

3 Federal University of Rio Grande do Norte,UFRN. Educational Center. Natal, Brazil.

4 Municipal Secretariat of Health of Parnamirim, Brazil.

5 Health Secretariat of State of Pernambuco, Brazil.

\section{Contact information:}

\section{Érico Gurgel Amorim.}

Address: 540 Dr. Carlindo de Souza Dantas St. Caicó, RN, Brazil. CEP: 59300-000.

Tel: +55 (84) 99458-2043.

” ericogur@gmail.com

Keywords

Visual Impairment; Mental Health; Mourning. 


\section{Introduction}

Visual impairment affects 35 million people, equivalent to $18.8 \%$ of the brazilian population, or $76.8 \%$ of all disabilities [1]. Despite this, according to the figures released by the Ministry of Labor and Employment (MTE) in the Annual Report on Social Information (RAIS) in 2015 , only 39,580 of the total of 381,322 jobs for people with disabilities refer to people with visual impairment. This is equivalent to $0.1 \%$ of brazilians who have visual impairment, which corroborates the high rates of inactivity among the individuals in this group [2].

One of the reasons is that the condition imposed by the absence of vision translates into a perceptive process that is reflected in the cognitive structuring and (re) organization and constitution of the psychological subject, with a direct reflection on mental health [3].

Thus, the triggering of a process of emotional and psychological alteration that is characterized by adjustment disorder and depression [4], higher suicide rates and lower life expectancy are highlighted among the problems related to visual loss [5].

In this context, people who are blind because they have a sensory deficiency of the vision suffer limitations in their possibilities of apprehending the external world, interfering in their development and adaptation to the different everyday situations [3]. As a result, loss of vision can lead to impairment of mental health, which predisposes to emotional losses, basic skills, professional activity and communication [6].

Therefore, there is a complexity of problems at the psychic and social levels that favor the progressive loss of the individual's ability to adapt to the environment. On the other hand, blindness induces anxiety and depression that impair social adaptation. When they last, they cause considerable levels of dependence and isolation [7].

The definition of mental health is strongly influenced by values, culture, and social context. It can be understood as a dynamic state of internal balance which, by allowing individuals to use their skills in harmony with the universal values of society, it enables them to deal with adverse life events [8].

A constitutive dimension of mental health is health itself, not only because of its value in enabling work and leisure activities but also because of its intrinsic value. Health or disability problems are another important risk factor for psychological well-being in general and depression in particular in individuals [9].

The study of mental health and its repercussions for visually impaired people are aligned with the values contemplated by the national health promotion policy, such as respect for diversity and social inclusion, aiming to mitigate risks and vulnerabilities related to social determinants of health [10].

Health promotion is essential for the rehabilitation and well-being of people living with chronic diseases or disabilities [11]. In this context, the National Policy for Health Promotion (PNPS) is focused on promoting equity and improving conditions and lifestyles, allowing health, autonomy and human potential to be vulnerability reduction and the risks from the social determinants of health, highlighting the cultural determinants [10]. It stands out for its inclusive and integrated content and it is aligned with the defense of universal human rights [12]. However, attention should be drawn among the challenges related to the effectiveness of this policy to the need for a focus on intersectoriality focused on specific groups such as the case of people with disabilities, allowing them to be fully included in the community [13].

The national health policy of the disabled person highlights the presence of close correlations between disability, impairment and mental health, contributing to varying degrees of limitation. It also states that the analysis of the health of people with disabilities must be carried out contemplating the multiplicity of existing socioeconomic and cultural variables, in order to overcome the current fragility in the health care of this population segment [14]. 
Therefore, the justification of this study is to reflect that the investigations on mental health in these populations are crucial, given the difficulties in identifying some behavioral problems and because they are often neglected and in disagreement with the directions intended by an inclusive society of fact and law. In this sense, inquiries led to the performance of this study: how does the acquisition of a visual impairment affect the life and mental health of the person who presents it and what emotional reactions can be demarcated in this process?

Thus, the objective was to understand the mental health of people with visual impairment in their particular life situations, identifying the stages of psychological suffering arising in the encounter with not seeing.

\section{Methods}

This is an exploratory research with a qualitative approach since it is understood that the object of study is circumscribed at levels of reality, where the data are presented to the senses as ecological and morphological levels, or as values, beliefs, representations, habits, attitudes, and opinions [15].

The study was carried out in a specialized outpatient clinic of ophthalmology in a university hospital in the city of Natal, Rio Grande do Norte, Brazil. At the beginning of the field study, a pilot study was conducted with two participants with severe visual impairment, and it was possible to test and improve the interview script. The information collected at this time did not compose the corpus of this work.

Fifteen adults were included in the ophthalmology outpatient clinic at a university hospital in the city of Natal, during the two months of data collection, in august and september of 2015. The study included people between 20 and 60 years old; who had acquired visual impairment for at least six months, defined by maximal visual acuity in both eyes and with the best possible optical correction below 20/200 (0.1 or 20\%) on the Snellen scale, or visual field equal or less than $20^{\circ}$ in the best eye, or the simultaneous occurrence of both [16]. These parameters are established by decree 3,298/99, which provides for the National Policy for the Integration of People with Disabilities [16]. Those who did not contemplate these deliberations did not participate in the study.

For the data collection, semi-structured interviews were recorded and transcribed in full, which included aspects related to the identification of respondents (age, gender, time of onset of visual impairment, education level, occupation, marital status, income). The specific questions to the objectives of the research were the strategies of coping with the acquisition of the visual deficiency, its impacts to the personal and social life and the reflexes in the mental health.

The analysis of the results was based on the theory of mourning proposed by Kübler-Ross [17]. Even the most mentally healthy individual will use mechanisms relevant to their adequacy to blindness, termed modes of coping, so the mourning theory [17] analyzes modes of coping through five stages called shock and denial, anger, bargaining, depression, and acceptance; which are described as follows: a) Shock and denial: stage in which when he becomes aware that he is sick, the patient reacts with a "no, I do not; it cannot be true." Usually, the patient goes into shock. b) Anger: step that appear the issues related to the process of getting sick, such as "Why me?", "Why now?". It is when the patient shows hostility to everyone around him; c) Bargaining: stage in which the patient tries to gratify by good conduct, aiming to gain more life; d) Depression: at this stage, the patient enters a moment of inner silence, closing in to say goodbye to the world, an important route to reach the last stage; e) Acceptance: when the patient apprehends his condition, he has already given up fear and anguish, showing himself in peace to face his destiny [17]. Between these processes, no behavior that the individual who experiences mourning will change 
the loss, so mourning is a process of adaptation. The way each person behaves in the face of this new reality is unique, each person has lived a distinct life history, so each one will deal with the moment in a special way and it is necessary to follow this particular process of each person [17].

The project was approved by the research ethics committee of the University Hospital Onofre Lopes of the Federal University of Rio Grande do Norte (HUOL/UFRN), under the number 1557507, according to research regulations involving human beings, respecting the precepts contained in resolution 466, of the National Health Council (NHC). All participants signed the Informed Consent Form (TCLE). In the characterization of the interviewees, they were identified from the nomenclature adopted, which attributed the letter $\mathrm{P}$, of research participants, followed by cardinal number, considering the secrecy of the interviewees.

\section{Results and Discussion}

In this space, the identification data of the study participants will be presented, and the analysis categories based on the mourning theory will be discussed [17].

\section{Participant identification data}

The 15 participants with visual impairment acquired were between 20 and 60 years old. Eight people were male and seven were female. The onset of visual impairment ranged from two months to 52 years. Most have incomplete elementary education or are illiterate. As for the occupation, retirees and people in inactivity predominate, with average family income between one and two minimum wages.

A model of coping has been proposed in which a person can experience a loss, mourning or tragedy suffered [17], providing subsidies for the psychological subject to reorganize, consisting of five stages: shock and denial, anger, bargaining, depression, and acceptance.
From the condition of acquired blindness, there occurs an imbalance in the previously complete subject in his physical body, that in a specific way, the confrontation can be seen as a psychological attempt of the subject to deal with this physical damage that comes up shaking his psychic structure. The interactions between physical and mental health are strongly identified [18]. Thus, confrontation is defined as the use of physical, psychological, cognitive and social resources to maintain somatic and psychic integrity and to achieve adaptation [18].

For a better understanding of this phenomenon, the visual impairment can be seen in different degrees, being able to be characterized as congenital blindness and acquired blindness. The congenital blindness refers to the one that the person is already born with, that is, before or during birth. In the acquired blindness, the person acquires it at any other period of life [19].

Consequently, there are experiential differences between congenital and acquired blindness, since the congenital blindness does not present feelings of loss since he has never had this experience, blindness to them is not insurmountable, tragic, since he developed and learned without this sense. However, acquired blindness causes a rupture in the already constituted patterns of communication, mobility, work, recreation, and feelings, becoming a traumatic experience [3].

However, whether in congenital or acquired impairments, the occurrence of a disability alters, to a greater or lesser degree, the lifestyles of the person, considering also the sociocultural universe in which he is immersed, since the conceptions, the explanations and the behaviors proper to that context are placed [20].

Also, while some researchers focus their questions on the analysis of difficulties arising from the absence or limitation of visual perception, others consider social conditions as the cause of the greater difficulties faced by the blind [3]. Meanwhile, in 
the present research, such situations overlap and interact in mutual and inseparable reinforcement, delineating the psychosocial and affective aspects of the subjects under analysis, in a web of interchangeable relationships.

There is no separation between mind and body, as well as an enormous influence of the social context on health and illness [21]. In this way, every symptom has a physical component, along with emotional and social components, which requires an integrated understanding of the human being. It is also worth mentioning the influence of life history, expectations for the future and the capacity for acceptance as influencers in the intensity and quality of the emotional apprehension built, particularly in the acquired disability.

From the psychological point of view, even the most mentally healthy individual will use important mechanisms for their adaptation to blindness. These mechanisms are known as coping modes [22].

According to the mourning theory, the shock state [17] may be one of the first reactions faced with a loss of vision and usually comes with the diagnosis. The individual becomes astonished, immobile, and lethargic temporarily because he needs time to absorb the idea. P3 and P14 exemplify this moment as follows:

I worked in agriculture and an ox cart turned on me and cut off my head. I saw my different vision and I went there at the clinic and I got there and said: Dr. I see something different, when he got there, he said: your retina is off, my friend. You will lose your sight. That was a shock to me, I was alone, I was desperate.

The beginning for me was desperation. The first days were very bad for me. Holy Mary! Darkness is bad.
In a research carried out from the analysis of documents, it was perceived as a general aspect, that the condition of blindness or low vision, at any stage of life, causes impacts on the social, physical and psychological aspects that can contribute to the formation of identity of individuals. Often, this condition becomes the only condition that the individual possessing it is recognized [23]; although as stated [24], the visual situation should not be a major factor in the construction of the subject's identity. They are constituted by a set of attributes that reveal themselves and denote who that person is, what their personality is, what makes them what they are. As a result, there is prejudice and social exclusion.

After the shock, a more or less short sub-phase of denial follows, a necessary moment for the subject's understanding of what is going on. This allows the psychic content to elaborate mechanisms that are adjustable to coping [17]. As can be seen below, P1 refers to:

Now then before, when I still saw a little, I did not have an impact that I did not even have recently, I had surgery to see if I had my retina glued in May 2015, May 12th, except that the retina took off on June $9^{\text {th }}$, less than a month. I did not believe it... Now that I even saw that I was visually impaired, because until $20 \%$ I did not consider myself visually impaired, I wanted to have a normal life, I wanted to have children, I had plans in my life, but unfortunately now the consciousness fell, so as I said, that I was visuaIly impaired, and the worst was the diagnosis, which has no more how to reverse, was irreversible. Now I'm trying to get over it because I still do not accepted it.

Over time, the person starts to use other defenses besides to denial, with the displacement of the problem to the other, which is seen as responsible 
for its adversity. The second stage, characterized by anger, in which the individual sees mutilated from his dreams and plans, is troubled by the external scenario to his momentary possibilities:

There is an hour that I am very upset, I am without rest, it is a terrible agony. It's something you cannot understand. The day I get worried about anything, at night I cannot sleep, thinking, I'm clear. I get very worried, angry because I cannot see.

Another phase of confrontation that may be present in the process of adaptation of the individual is the bargain. This is characterized by the individual's action to negotiate exchanges between the unconscious and the real through the fanciful, that is, the individual believes that he will eliminate the problem with a magical resolution, like the person who turns to God to obtain the visual restitution [17]:

I have faith in God that I will regain my sight. Faith removes mountains. I'm Catholic. But I have faith in God. Nothing for God is costly. I have faith in God that my sight will return to normal. Have not I lost my sight at once? I still see. I have great faith in God, but I will return to normal.

The reports show a strong religious component in which projections, goals, and dreams are anchored, which allow the elaboration of a strategy of confrontation based on hope, whether to re-view, to stabilize the clinical picture, or simply to protect oneself.

Sadness, anguish, and depression are recurring marks at some point in the lives of those interviewed. Most of them showed these feelings when faced with visual loss, with a loss in their quality of life. Several causes are mentioned: the visual loss, the lack of knowledge of how to face it, lack of faith, the stop of professional life, the way to receive the news of the disability by the doctor, isolation, and loss of autonomy:

I suffered an accident in 2003, I was hit by a bus, and a month later I began to give the problem of retinal detachment in my eye. Then I did several surgeries, but there was no way: complete blindness. The doctor spoke like that. I was seeing everything pink, he examined and said... Unfortunately, you will lose your sight! I do not know if tomorrow or a week from now... but you will lose your vision. It was very traumatic and he was hard enough. Prepare yourself psychologically and advise to seek the Institute of the blind. And it was that way. I think I was more depressed because of this too because I did not have a preparation, it was automatic.

Through the report by P8, it was possible to emphasize that he went through a depressive episode [25], a characteristic marked in his speech:

I had a very active life, then when I lost, I stayed indoors, I locked up, it was difficult for me to accept. That was it, I went through this process two years.

The feeling of impotence characteristic of the observed depression phase in the speech of P8 is highlighted. Although presenting negative potential, this impotence can be an important step towards real acceptance and coping with the situation [26, 27].

In the process of mourning, depression assumes a reactive character to the loss of health and conceives a phase imperative to the psychic task of coping. If avoided, it may negatively impact the subject's adaptation to his/her new condition. And if excessive, it becomes pathological [27]. 
The last stage of acceptance or accommodation is described [17] as a possibility of understanding what was lost, in what portion was this loss and how this will influence the life of this individual now with limitations to his actions.

In this way, the subject becomes able to live with his limitations integrating them in his life:

Me are handle it... And you have to smile, play... that crying does not work... You have to spend the day anyway, I'm too satisfied and I want to live until my children have already turned... I just hope that there, every day more the routine download. And the woman says anything I leave pulling you. And I say because I really need it. My strength is God and she is my guide.

The acceptance process can also mobilize those around you: family, friends, community. P8 refers to difficulties in the family understanding of their condition, which may delay the acceptance process or even make it unfeasible, considering the representativeness that family support exerts at this moment:

I had a vl already accepted, but they still have that difficulty of realizing that someone is blind in the house or in the family... it was difficult for me to accept it...

For the victim of blindness acquired in adulthood, this accommodation may or may not happen, as it will depend on the intensity of the loss being felt. P5 expresses a partial acceptance state:

I was slow to accept this vision problem. I think I'm not even accepting it right.

The task of accepting the changes brought about by loss of vision is not an easy process, nor is it immediate. As a result of loss of vision, other losses occur their interests, their aspirations, their social position, their capacity, their appearance and their friends [28]. At first, the person can react by expressing their feelings of anger, depression or regret, and then they begin to become aware of their condition, limits, and possibilities, which relate intrinsically to one's own history and to one's internal and external resources:

That's when I started to see with different eyes, right? Eyes that are not so disabled, right? And then I think that way, the life continues, and that is a difficulty, of course, I will not cover the sun with the sieve, I became deficient at almost 30 years old, I will be 29 now, and that is it's going to be difficult, but I will not be able to do it, but if I put it that way I'm going to get it, it's going to be one day after another, that's what I'm doing living, I'm living the today and tomorrow is going to be another day and every day I'm looking to adapt it to the deficiency.

Although technically and legally valid, the proposed phases [17] establish a picture of possible existentialism, regarding the psychological manifestations, inspired by the process of the emergence of a disability. However, this reality does not apply to congenital deficiency, not represented by the sample participants. Thus, as directive and non-imperative measures, these phases incorporate new psychic prisms into the confrontation aroused by the difference mark.

In this way, confronting requires a posture of the subject of encounters with the stranger in himself, relearning own ways of facing each other. Acceptance, in this perspective, requires considering reinforcing instruments of self-esteem, self-confidence, social support and micro, and macro social apparatuses, in which the subject is constituted.

Thus, health implies being able to become ill and leave the pathological state. In other words, health is understood as the probability of facing new cir- 
cumstances, by the condition that each individual has to face and overcome the adversities of the environment [29].

This new stage will be more easily achieved as the social practices permeable to the cultivation of the valorization of diversity are established, sowing and harvesting inclusive, humanitarian and full citizenship actions.

Thus, the universal access of the disabled people to the health services must be protected, including the active search and the necessary adaptation to the reception, guaranteeing the right to health and the health promotion of this segment of the population, with the multi-professional participation and engagement of the actors involved. By focusing on mental health care, qualified listening, free access, and transit at the various levels of the health system, there is an approach to care committed to the rescue of citizenship, social integration, respect and appreciation of those who face a disability in their expressions of life.

\section{Conclusions}

From the objective of analyzing the mental health of the condition of visual impairment, identifying the stages of psychological suffering in the encounter with the not see we consider that the diagnosis and the assimilation of a visual deficiency reverberate in the subjectivity and anticipate new existential realities that they require coping approaches. In the meantime, the mode of installation, the age of involvement, the presence of comorbidities or pain, the degree of disability and the ability to cope with adversity are key elements in the way visual loss is experienced.

There is a component of suffering associated with every disease, sometimes acting as an obstacle to preventive practices for a healthier life. As a result, every health problem is also mental health and all mental health is also health production.
Facing the condition of visual impairment, the constitution of the psychological subject involves the individual and collective dimensions. At the individual level, interactions between physical and mental health are identified among the structuring ways of facing the condition of not seeing, through living the stages of mourning, in a process of reconstruction, characterized by shock and denial, anger, bargaining, depression, and acceptance in particular life histories. Such reality was evidenced only in cases of acquired visual loss, while in congenital deficiency, the subject constructs his identity without perceptible ruptures, naturalizing the sensorial difference.

In an emancipatory proposal, the release of the jail around the visual deficiency is established unveiling the psychic suffering that fogs the relation with itself and with the other. This will allow the reestablishment of the bonds and reins of life, characterized as pathological to re-emergence as normative, in the process of social inclusion. However, this inclusion undeniably sought and legally foreseen, and can only be realized as the universal rights to a dignified and interactive life are established, allowing the scope of difference in the equality of human beings that gives them existence.

With this study, it was tried to reinforce the link of the investigation by the sayings and interdicts of the reason and the finding of their strangers and the society between places. This allowed for a reflexive and critical approach concerning the contemporary reality of people with visual impairment and how they react to the infidelities of the environment, which are peculiar to them.

The challenges revealed here recruit collective efforts from management bodies and society as a whole, aiming at promoting the mental health of the visually impaired, guaranteed by their full participation in the community environment and respect for their own differences. 


\section{Development agency}

Coordenação de Aperfeiçoamento de Pessoal de Nível Superior, CAPES, Brasil.

\section{Conflict of interest}

There was no conflict of interest recorded.

\section{References}

1. Instituto Brasileiro de Geografia e Estatística. Censo 2010 [Internet]. 2010 [acesso em 2017 Jun 12]. Disponível em: http:// censo2010.ibge.gov.br

2. Brasil. Ministério do Trabalho e do Emprego. Relação anual de relações sociais [Internet]. 2015. [acesso em 2017 Jun 21]. Disponível em: http://portal.mte.gov.br/observatorio. Atualizado

3. Amiralian MLTM. Compreendendo o cego: uma visão psicanalítica da cegueira por meio de desenhos-estórias. São Paulo: Casa do Psicólogo, 1997.

4. Nispen RMA, Vreeken HL, Comijs HC, Deeg DJH, Van Rens GHMB. Role of vision loss, functional limitations and the supporting network in depression in a general population. Acta ophthalmologica. 2016; 94(1): 76-82.

5. Zhang $T$, Jiang $W$, Song $X$, Zhang $D$. The association between visual impairment and the risk of mortality: a meta-analysis of prospective studies. J Epidemiol Community Health. 2016; 7(8): 836-42.

6. Brasil. Ministério de Educação. Secretaria de Educação à Distância. Deficiência visual. Brasília: MEC, Secretaria de Educação a Distância [Internet]. 2000 [acesso em 2016 Set 2017]. Disponível em: http://www.mec.gov.br/seed/tvescola.

7. Van der Aa HP, Comijs HC, Penninx BW, Van Rens GH, Van Nispen RM. Major depressive and anxiety disorders in visually impaired older adults. Invest Ophthalmol Vis Sci. 2015;56(2):849-54.

8. Galderisi S, Heinz A, Kastrup M, Beezhold J, Sartorius N. Toward a new definition of mental health. World Psychiatry [periodic on the Internet]. 2015 [cited 2017 Jun 10]; 14(2):231-33. Available in: https://www.ncbi.nlm.nih.gov/pmc/articles/PMC4471980/ pdf/wps0014-0231.pdf.

9. Prince M, Patel V, Saxena S, Maj M, Maselko J, Phillips MR, et al. A. No health without mental health. The Lancet Psychiatry. 2007; 370(9590): 859-77.

10. Brasil. PRC $n^{\circ}$ 2, de 28 de setembro de 2017, Anexo I, Capítulo I. (Origem: PRT MS/GM 2446/2014, Art. 6) [Internet]. 2017 [acesso em 2018 Maio 10]. Disponível em: http://bvsms.saude. gov.br/bvs/saudelegis/gm/2017/prc0002 $03 \quad 10 \quad$ 2017.html.
11. Eagle D, Chan F, Iwanaga K, Reyes A, Chiu CY, Bezyak J et al. Health Promotion for People with Disabilities: A Primer for Rehabilitation Counsellors. The Australian Journal of Rehabilitation Counselling. 2017; 23(2): 1-14.

12. Silva Munguba MC, Vieira ACVC, Porto CMV. Da invisibilidade à participação social: promoção da saúde em pessoas com deficiência. Revista Brasileira em Promoção da Saúde. 2015; 28(4): 463-465.

13. Malta DC, Morais Neto OL, Silva MMAD, Rocha D, Castro $A M D$, Reis AACD, Akerman M. Política Nacional de Promoção da Saúde (PNPS): capítulos de uma caminhada ainda em construção. Ciência \& Saúde Coletiva. 2016;21(6), 1683-94.

14. Brasil. PRC $n^{\circ} 2$, de 28 de setembro de 2017, Anexo I do Anexo XIII. (Origem: PRT MS/GM 1060/2002) [Internet]. 2017. [acesso em 2018 maio 10]. Disponível em: http://bvsms.saude.gov.br/ bvs/saudelegis/gm/2017/prc0002 $03 \quad 10$ 2017.html.

15. Minayo MCS. O Desafio do Conhecimento. $11^{\mathrm{a}}$ ed. São Paulo: Hucitec, 2008.

16. Brasil. Decreto n. 3.298, de 20 de dezembro de 1999. Regulamenta a Lei $n^{\circ}$ 7.853, de 24 de outubro de 1989, dispõe sobre a Política Nacional para a Integração da Pessoa Portadora de Deficiência, consolida as normas de proteção e dá outras providências [Internet]. 1999 [acesso em 2017 mar 29]. Disponível em: http://www.planalto.gov.br/ccivil 03/decreto/ D3298.htm.

17. Kübler-Ross E. Sobre a morte e o morrer. $9^{\circ}$ ed. Martins fontes. 2008.

18. Kovács MJ. Deficiência adquirida e qualidade de vida: Possibilidades de intervenção psicológica. In Becker E, Masini EAFS, Pinto EB, Amaral LA. 1997.

19. Almeida TS. Diferenças experienciais entre pessoas com cegueira congênita e adquirida: uma breve apreciação. Revista Interfaces [periódico na Internet]. 2013 [Acesso em 2017 Jul 10]; 1(3). Disponível em: http://www.interfaces.leaosampaio.edu.br/ index.php/revista-interfaces/article/viewFile/24/29.

20. Pereira R. Anatomia da diferença. Normalidade, deficiência e outras invenções. São Paulo: Casa do Psicólogo, 2008.

21. Fernandes WJ. Saúde mental: uma visão vincular. Rev. SPAGESP [periódico na Internet]. 2009 [Acesso em 2016 Set 24]; 10(2). Disponível em: http://pepsic.bvsalud.org/scielo.php?script=sci arttext\&pid=S1677-29702009000200004\&lng=pt\&nrm=iso.

22. Barczinski MCC. Reações psicológicas à perda da visão. Revista Benjamin Constant [ períodico na Internet]. 2001 [Acesso em 2017 Abri 15]; 18. Disponível em: http://www.ibc.gov. br/?itemid $=110$. 
23. Dalgalarrondo P. Psicopatologia e semiologia dos transtornos mentais. Porto Alegre: Artmed Editora, 2008.

24. Felicett S A; Santos S A dos. Santos S, Santos E M. A utilização das tecnologias assistivas com pessoas cegas ou com baixa visão: uma revisão da literatura. Br. J. Ed. Tec. Soc., v.10, n.4, Out.-Dez., p.275-287, 2017.

25. Amiralian, M L T M. Sou cego ou enxergo? As questões da baixa visão Am I blind or seeing? The questions of low vision. Educar em Revista, n. 23, p. 15-28, 2004.

26. Holland JM, Kübler-Ross E. IN: Brennan MJ. (Ed.), The A-Z of death and dying: Social, medical, and cultural aspects (pp. 286288). doi: 10.13140/RG.2.1.3863.2401. 2014.

27. Simonetti A. Manual de psicologia hospitalar: O mapa da doença. São Paulo: Casa do Psicólogo. 2011.

28. Moreira FDS. A aceitação e o enfrentamento da cegueira na idade adulta. [dissertação]. São Carlos(SP): Universidade Federal de São Carlos, Programa de pós-graduação em educação especial; 2004.

29. Canguilhem GO. Normal e o Patológico. $6^{a}$ ed. Rio de Janeiro: Forense Universitária, 2009.

Publish in International Archives of Medicine

International Archives of Medicine is an open access journal publishing articles encompassing all aspects of medical science and clinical practice. IAM is considered a megajournal with independent sections on all areas of medicine. IAM is a really international journal with authors and board members from all around the world. The journal is widely indexed and classified Q2 in category Medicine. 